\title{
I.Г. Савка
}

\section{ПЕРШИЙ ДОСВІД РЕАЛІЗАЦІЇ ПРАВА НА АКАДЕМІЧНУ МОБІЛЬНІСТЬ УЧАСНИКІВ ОСВІТНЬОГО ПРОЦЕСУ В БДМУ}

Вищий державний навчальний заклад України «Буковинський державний медичний університет», м. Чернівці

Резюме. У статті відображені основні моменти в ході імплементації права на академічну мобільність серед учасників освітнього процесу в БДМУ згідно з новими регламентуючими документами в цьому напрямі. Показана роль академічної мобільності, як вагомої

Вступ. Імплементація права на академічну мобільність $є$ вагомим фактором, що сприяє ширшій інтеграції вітчизняної вищої медичної освіти в Міжнародний освітній простір. Завдяки йому учасники освітнього процесу мають змогу здобути нові знання і досвід у провідних вищих навчальних закладах Європи, перейняти нові технології й методики викладання різноманітних навчальних дисциплін, вдосконалити рівень англійської чи будь-якої іншої з Свропейських мов, представити свій навчальний заклад міжнародному освітньому товариству.

Сприяє імплементації вказаного права «Положення про порядок реалізації права на академічну мобільність», затверджене Постановою Кабінету Міністрів України від 12 серпня 2015 р. за № 579 [1].

Інтегруючим чинником $\epsilon$ також порядок організації навчального процесу у вищих навчальних медичних закладах України, який у переважній більшості вишів здійснюється за Європейською кредитно-трансферною системою (СКТС) організації освітнього процесу [2].

Викладання навчальних дисциплін англійською мовою разом із СКТС значно спрощують взаємний академічний обмін студентами й викладачами між різними вищими навчальними закладами Європи, сприяють інтеграції та підвищенню рівня якості освіти і міжнародних освітніх контактів [3].

Мета дослідження. Відобразити ключові моменти у процесі реалізації права на академічну мобільність згідно з новими регламентуючими державними документами у цій сфері освітньої діяльності.

Основна частина. Упродовж 2005-2016 навчальних років студенти і викладачі ВДНЗ України «Буковинський державний медичний університет» проходили стажування у провідних клініках університетів Німеччини, Австрії, Польщі, Італії, Іспанії, Молдови, Румунії та ін. у рамках літньої виробничої практики й академічного взаємного обміну.

Із прийняттям «Положення про порядок реалізації права на академічну мобільність», затвердженого Постановою Кабінету Міністрів України за № 579 від 12.08.2015 року, імплементація права на академічну мобільність серед студентів-меди- складової у процесі інтеграції вищої медичної освіти України у Міжнародний освітній простір.

Ключові слова: академічна мобільність, освітній процес, медична освіта.

ків та викладачів нашого університету набула більш інтенсивного та організованого характеру.

Нове Положення упорядковує організацію програм академічної мобільності для всіх учасників освітнього процесу вищих навчальних закладів на території України та за її межами й учасників освітнього процесу іноземних вишів чи наукових установ на території України.

Згідно з ним, академічна мобільність поділяється на внутрішню - право, на яку реалізується вітчизняними учасниками освітнього процесу у вишах-партнерах у межах нашої держави, та міжнародну - право, на яку реалізується вітчизняними учасниками освітнього процесу у вишахпартнерах поза межами України, а іноземними учасниками освітнього процесу у вищих навчальних закладах України. При цьому учасники освітнього процесу, які є здобувачами вищої освіти в межах програм академічної мобільності, зараховуються до вищих навчальних закладів чи наукових установ-партнерів в Україні як такі, що тимчасово допущені до освітнього процесу і мають права та обов'язки здобувачів вищої освіти вітчизняного вищого навчального закладу.

Дане Положення впорядковує і форми академічної мобільності. Для учасників освітнього процесу, які здобувають освітні ступені молодшого бакалавра, бакалавра, магістра та доктора філософії у вітчизняних вищих навчальних закладах, ними є навчання за програмами академічної мобільності, мовне стажування та наукове стажування. Для осіб, які здобувають науковий ступінь доктора наук, науково-педагогічних працівників та інших учасників освітнього процесу такими є участь у спільних проектах, викладання, наукове дослідження, наукове стажування та підвищення кваліфікаиії.

Упродовж 2015-2016 н. р. на навчання за взаємним обміном до ВДНЗ України «Буковинський державний медичний університет» прибуло двоє громадян Італії - студентів університету Фоджа, які вибрали наш навчальний заклад з-поміж багатьох інших вищих навчальних медичних установ Європи.

Вказані іноземці були зараховані на навчання студентами медичного факультету №3 на правах учасників освітнього процесу, як здобувачі вищої медичної освіти 3 вивченням навчальних 
дисциплін англійською мовою, передбачених Програмою для студентів 3-го курсу спеціальності «Лікувальна справа» на умовах Програми Міжнародного академічного обміну Erasmus + (Key Action 1 - Mobility for Learners and Staff. Higher Education Student and Staff Mobility).

У той же час вітчизняні студенти БДМУ за вказаною та іншими програмами академічного обміну навчалися в університетах Фоджа (Італія), Арістотеля (Салоніки, Греція), Сантьяго-деКомпостела (Іспанія) та ін.

Упродовж останніх років набирає обсягів i взаємний академічний обмін викладачами. Так, як приклад можна привести стажування викладачів БДМУ в Литовській республіці (м. Каунас) у Литовському університеті наук про здоров'я та Республіканській каунаській клініці в рамках програми «Співпраця Україна-Литва під егідою НАТО». Група із 15 осіб науково-педагогічного складу нашого університету в період 14-18 березня 2017 року відвідали університетську клініку, центр невідкладної та екстреної допомоги, центр реабілітації та симуляційний центр Литовського університету наук про здоров'я, таким чином підвищивши як свою загальну педагогічну, так і кваліфікацію за окремими спеціальностями та поглибивши Міжнародну співпрацю у рамках Євроінтеграційного напряму.

\section{Висновок}

Імплементація права на академічну мобільність студентів і викладачів між навчальними закладами-партнерами в рамках Міжнародних програм $\epsilon$ вагомою складовою інтеграції вищої медичної освіти України у Міжнародний освітній простір.

\section{Література}

1. Положення про порядок реалізації права на академічну мобільність. Затверджене Постановою Кабінету Міністрів України від 12 серпня 2015 р. № 579.

2. Європейська кредитна трансферно-накопичувальна система в контексті реформування англомовного навчання іноземних студентів у Львівському Національному медичному універстеті імені Данила Галицького / [Зіменковський Б.С., Гжегоцький М.Р., Варивода Є.С. та ін.] // Мед. освіта. - 2016. - № 2. - С. 110-112.

3. Англомовне навчання як стимулятор якості освіти та міжнародних контактів / В.М. Запорожан, В.Й. Кресюн, М.Л. Аряєв, О.В. Чернецька // Мед. освіта. 2011. - № 2. - C. 45-47.

\section{ПЕРВЫЙ ОПЫТ РЕАЛИЗАЦИИ ПРАВА НА АКАДЕМИЧЕСКУЮ МОБИЛЬНОСТЬ УЧАСТНИКОВ ОБРАЗОВАТЕЛЬНОГО ПРОЦЕССА В БГМУ}

\section{И.Г. Савка}

Резюме. В статье отображены основные моменты в ходе воплощения права на академическую мобильность среди участников образовательного процесса в БГМУ согласно с новыми регламентирующими документами в этом направлении. Показана роль академической мобильности, как весомой составляющей в процессе интеграции высшего медицинского образования Украины в Международное образовательное пространство.

Ключевые слова: академическая мобильность, образовательный процесс, медицинское образование.

\section{THE FIRST EXPERIENCE OF THE LAW IMPLEMENTATION TO ACADEMIC MOBILITY FOR PARTICIPANTS OF THE EDUCATIONAL PROCESS IN BSMU}

\section{I.H. Savka}

Abstract. The article reflects the main principles in the course of law implementation to academic mobility among the participants of educational process in BSMU according to new regulating documents concerning this issue. The role of academic mobility is indicated as a substantial constituent in the process of Ukrainian higher medical education integration into International educational space.

Key words: academic mobility, educational process, medical education.

Higher State Educational Institution of Ukraine «Bukovinian State Medical University» (Chernivtsi)

Рецензент - доц. І.В. Геруш

Buk. Med. Herald. - 2017. - Vol. 21, № 2 (82), part 1. - P. 177-178

Надійшла до редакції 04.04.2017 року

(C) І.Г. Савка, 2017 